\title{
Cultural sensitive readings of Nahum 3:1-7
}

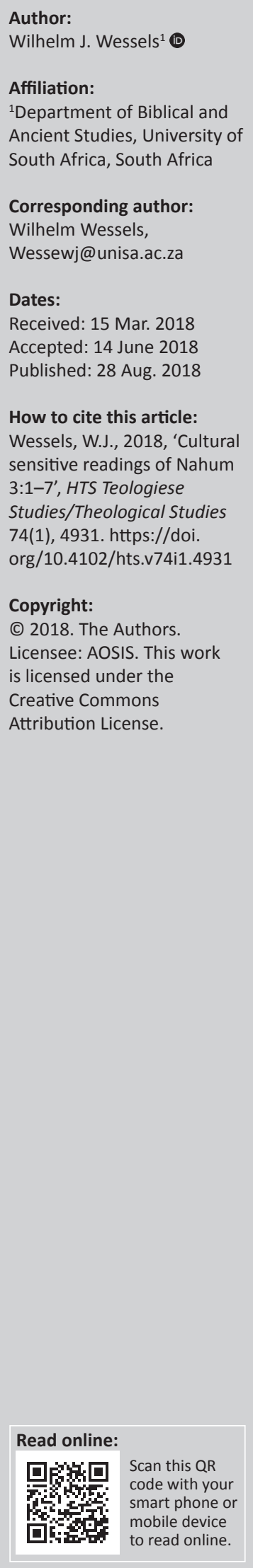

The text of the book of Nahum poses many challenges to exegetes and readers of the text. Nahum 3 in particular, challenges modern readers with its violent imagery and the derogatory language towards women. The article attempts to propose cultural sensitive readings of two different 'cultures', namely, reading Nahum in its historical context and from a perspective of feminist interpretation. Most serious exegetes agree that the reading of texts, in this case, a prophetic text, should first and foremost be interpreted in its historical and social context. It is also true that readers or hearers of the text react to and give meaning to the text. Our cultural embeddedness plays a major part in the process of 'meaning-giving' to the texts we interpret. The argument put forward in this article is that interpreters should be accountable for the meaning they ascribe to and promote of a particular text.

\section{Introduction}

The book of Nahum is an extraordinary book. The three chapters of the book display creative poetry, a variety of vivid imagery and intriguing content. The book is renowned for its provocative language and imagery. While there is compassion by many readers to the plight of the Judean people being oppressed by the Assyrian world power, the way their cause is championed raises many questions. Nahum 3, in particular, has raised many an eyebrow and sparked much debate. To mention just some of the controversial imagery, chapter 3 displays scenes of carnage (3:3), the city Nineveh is depicted as a harlot (3:4), displayed naked as a form of humiliation (3:5) and the Assyrian soldiers are compared with women to accentuate their weakness (3:13). It should, however, be recognised that Nahum is an ancient text, written in a particular cultural context, reflecting social conventions of a particular time and context. This, in fairness, should be taken into account when interpreting Nahum, therefore a culturally sensitive reading is required. The term culture is difficult to define. Merriam-Webster ${ }^{1}$ defines culture as:

the beliefs, customs, arts, etc., of a particular society, group, place, or time: a particular society that has its own beliefs, ways of life, art, etc.: a way of thinking, behaving, or working that exists in a place or organization (such as a business).

The intention is not to provide an exhaustive discussion of its meaning, but give a working definition thereof. For the purpose of this article, I understand culture broadly as the customs, values and beliefs that people hold. It can be the common and distinct customs, values and beliefs of a particular nation, ethnic group, a particular tradition (e.g. religious tradition) or an interest group (e.g. Feminism). Culture is also informed by geographical location, a period in history and a particular Zeitgeist.

The issue of concern in this article is to read Nahum 3 with a sensitivity for its cultural embeddedness, but at the same time with an awareness of readers' social and cultural preferences and conventions. Modern readers of the Nahum text are also socially and culturally situated, affecting how they understand and judge ancient texts. Besides considering the sociocultural context of the Nahum 3 text, a discussion will be offered on how feminist biblical critics as an expression of a modern 'culture' respond to the use of female metaphors in general. To illustrate this critique more concretely, the interaction with Nahum 3 by one particular feminist reader, will be presented.

\section{A reading sensitive towards the ancient culture of the Nahum text}

In this section attention will be given to Nahum 3:1-7, showing sensitivity for the socio-historical context of the text. The methodology followed takes linguistic as well as socio-historical matters into consideration.

1.Merriam-Webster, https://www.merriam-webster.com/dictionary/culture, viewed 02 March 2018. 


\section{Exposition of Nahum 3:1-7}

The main focus of this chapter is the downfall of Nineveh. Whereas chapter 2 is a visionary account of the battle and invasion of Nineveh, the focus of the new oracle in chapter 3 is on the nature and the fate of Nineveh. In verses 1-17, Nineveh and its people are addressed, and in verses 18-19 the king who rules from Nineveh. Nahum 3:1-17 can further be subdivided into verses $1-7$ and $8-17$. For the purpose of this article, the focus will be on Nahum 3:1-7.

Nahum 3:1-7 is a threatening speech against Nineveh. Tuell (2016:39) calls this oracle a taunt song, but also in reference to 3:7 a satirical lament. Verses 1-3 are a woe-oracle, verse 4 gives the reason for the woe-oracle, followed by the judgement (punishment) in verses 5-7.

Verse 1 is introduced by the 'woe' הi-particle to set the tone of a funeral. A cry of mourning is uttered over Nineveh, called 'the city of blood' (cf. Is 10:5ff.; Dietrich 2014:76-77). Although the name of this 'city of bloodshed' is not revealed at this stage of the section, it is clear from the broader context that Nineveh is in mind (cf. 2:8 - Heb 2:9; 3:7 and the reference in 3:18 to the king of Assyria; Coggins \& Han 2011:30). Floyd regards the call for people to mourn Nineveh as a sarcastic lamentation of the city suffering the consequences of her actions against the nations (Floyd 2000:69). Nineveh is the place where all the military and political actions of Assyria were planned and is, therefore, to be associated with all the bloodshed caused by the Assyrian army. To add to this, the existence of the city is characterised as a lie, a city of deceit, full of plunder, never without booty. The terminology used here reminds of the visionary oracle in chapter 2 . The city is to be mourned because it is founded on the misery and at the expense of other nations.

In verses $2-3$ the poet is at his very best again. As in chapter 2:9-10 the staccato-style is applied to describe a battle scene. By the listing of different events, a quick shift in focus is created, leaving the impression of speed and movement on the audience. The prophet succeeds by involving his audience in the role of observers. Robertson (1990:104-105) points to the progression displayed in this verse by the vivid description of an attack taking place. A battle is taking place and is described from the first crack of the whip to the resulting scene of dead bodies. Verse 2 describes the cracking of the whip, the rattle of wheels, horses galloping and chariots bouncing. Verse 3 follows with scenes of charging cavalry, flashing swords and glittering spears. The result of all of this is a great number slain, a mass of corpses, dead bodies without end, and people stumbling over the bodies. Dietrich (2014) describes the result of using swords and spears as gruesome. He says:

Das grausige Werk, das sie anrichten, sieht man gleich anschließend vor sich liegen: Massen von 'Durchbohrten' und 'Leichnamen'. Das Begriffspaar begegnet im Parallelismus membrorum auch in Jes 34,3; Jer 41,9; Ez 6.5. Es ist die Sprache von Kampf, Blutvergießen und Tod, die hier gesprochen wird. (p. 78)
The impression left by these gruesome depictions validates the mourning cry 'woe' that sets the tone of this oracle against Nineveh. When reading the account of the battle scene one might have the idea that it is a description of the destructive power of the Assyrian army. However, in the next verse, it becomes clear that, ironically, the Assyrians are the actual victims of a power that supersedes theirs.

Verse 4 explains the reasons for the defeat of Nineveh in

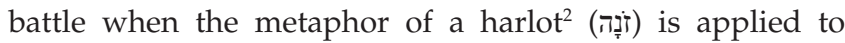
explain the actions of Nineveh. It is interesting to note that she is described both as attractive and as a harlot. This describes how dangerous this woman really is. The figure of speech of a harlot is often used in Biblical literature to characterise the misbehaviour of people or nations (cf. Is 1:21, 23:16; Ezk 16, 23; Ho 5:4; Rv 17-18). Nineveh is called a harlot who has committed countless harlotry acts. O'Brien (2009) says of the use of the term harlot the following:

Nahum, having inherited the tradition of personifying cities as women, uses the culture's definition of the worst kind of woman, the whore, as a slur by which to demean Nineveh. (p. 61)

The idea is that of a woman seducing men: she is graceful and of deadly charms. Nineveh has made many pacts and agreements with other nations and has seduced them into treaties with the intention of dominating and exploiting them, both politically and economically (Floyd 2000:70). A possibility that needs consideration when speaking of prostitution in this context is the seduction of the people of Yahweh to worship foreign gods. This was a constant threat which the prophets of the Old Testament warned the people of God against. In this regard, the allusion might be to the worship of the goddess Ishtar, often depicted in sexual terms (Coggins 1985:49). Tuell (2016) says in this regard:

This combination of sexual rapacity and supernatural power sounds like a description of the goddess Ishtar, the embodiment of female sexuality in Mesopotamia. Ishtar's association with the planet Venus, which is both the morning and evening Star, indicates her duality. As the embodiment of wifely virtues, she represents 'safe' sex and fertility; however, she also represents dangerous passions, and so it embodies prostitution and warfare. Nineveh was associated with Ishtar from ancient times. (p. 42)

It is clear from this verse that any involvement with Nineveh was detrimental. For these reasons, Nineveh will become the object of Yahweh's judgement. The destructor will become the destructed.

In verses 5-7, Yahweh of hosts (Almighty) addresses Nineveh in the first person singular. This subsection is introduced by the word 'behold' or 'pay attention', followed by the announcement of judgement on Nineveh. Judgement is introduced by a formal declaration: 'I am against you'. By means of the metaphor of nakedness, it is stated how Yahweh will punish Nineveh. He will lift

2.0'Brien (2009:60-61) discusses the term which has the literal meaning of a professional prostitute, but figuratively can refer to a promiscuous woman. Besides figuratively referring to promiscuous woman, it can also imply religious unfaithfulness. 
her skirt ${ }^{3}$ over her face, therefore revealing her nakedness. Tuell (2016:43) indicates that the noun ma'ar (טַַע - bare or nakedness) only occurs here and in Kings 7:36 in an unrelated use. The noun, however, is related to 'erwah -nakedness - and when used with the verb 'to uncover' - galah (גלה), it 'is to engage in shameful, defiling sexual intercourse, particularly incest or sexual relations with a menstruating woman' (cf. Ezk 16:37-41; 22:10, 18'; Tuell 2016:44). However, it can also be used metaphorically to indicate the rape of cities personified as women as is the case in Nahum 3:4-7. In this verse (verse 5), nations are linked with kingdoms and nakedness to shame. Yahweh will punish Nineveh by humiliating the city before the nations. He will make a public spectacle of Nineveh. The harlot of verse 4 will receive fitting punishment (cf. Is 47:1-3). Assyria, with Nineveh as the seat of power, dominated Israel and Judah for a large part of the 8th and 7th centuries BCE and oppressed many of the nations (Nelson 2014:123-136). The city will, however, lose its position of dominance, but it will not remain a secret to the nations. Nineveh can no longer pretend to be in control, for Yahweh will reveal her shame, her vulnerability, to the nations and they will see that Nineveh is powerless. Dietrich (2014:81) argues: 'Es geht hier nicht um Vergewaltigung, sondern um politisch motivierte Bestrafung in form von Entehrung'. This is a reversal of fates. When Nineveh invaded cities, the captives were humiliated by stripping their clothes from them, leaving them naked in public as an indication of their defeat.

Tuell (2016:44) thinks that more is implied here than simply the metaphorical depiction of Nineveh's fall. He argues that it was common practice when soldiers invaded cities that they would also rape the women in the city as part of the spoils of war. He suggests that Nahum had in mind that this is actually what the women of Nineveh would also experience when the city is invaded by the enemy. If this interpretation holds ground, then it implies that Yahweh will see to it that Nineveh receives similar treatment. It, however, seems that the argument Tuell promotes, relies on the assumption of rape accompanying invasions and that this was what Nahum intended with his use of the metaphor of 'uncovering the woman's nakedness'. This assumption of Tuell is perhaps stretching it too far. We will come back to this aspect when referring to modern interpretations of this passage.

Verse 6 continues the picture of Nineveh's imminent defeat through Yahweh's intervention. It will be nothing less than an utterly humiliating experience. He will show his contempt for the city by throwing filth (excrement) at her and making a spectacle of her (Coggins \& Han 2011:31). Nothing will be left of Nineveh's image.

Verse 7 concludes this first part of the woe-oracle by making it explicit that it is Nineveh who is the object of Yahweh's judgement. But it is clear that Nineveh will no longer have any power over nations, because they will free themselves from the Assyrian dominance and flee. To the prophet, the 3.Spronk (1997:123) indicates that שוּ denotes the genitalia. reality of Nineveh's defeat is so certain that he can say: 'Nineveh is in ruins'. This statement is followed by two rhetorical questions which give a clear impression of feelings about Nineveh. It is asked: 'Who will mourn for her?' and the implied answer is - nobody! 'Where can I find anybody to comfort $^{4}$ you?' And the answer is - nowhere! The use of the verb 'to comfort' here is possibly a pun on the name of the Nahum (נחם; Spronk 1997:125). His message has the purpose of comforting his people who are oppressed by Assyria. However, there will not be anyone to comfort Assyria.

\section{Ancient texts and the use of metaphors}

Without a doubt, the metaphors used in the book of Nahum are violent and offensive. The theoretical study of metaphors has received much attention lately and is clearly a very complex and diverse matter (cf. Van Hecke 2005:1-3). ${ }^{5}$ For the purpose of this article, however, a few remarks on metaphors will suffice. Jindo (2010) defines a metaphor as:

a mode of expression, whereby one thing $(\mathrm{A})$ is understood and described in terms of another (B); The relationship between the two things (A and B) is that they belong to different conceptual domains. (p. xiii)

Jindo also distinguishes between the general use of metaphors in everyday communication and the use of metaphors in poetry. He says of the use in poetry that 'the cognitive force of metaphors may be fully operative and designed to reframe or restructure the conceptual knowledge of the reader' (Jindo 2010:32). The author of the text using the metaphor would add not only to the conceptual knowledge of the reader but in the case of a prophetic text also of the hearer of the prophetic word. The poetic use of metaphors in Nahum is important because this text is lauded for its poetic quality. I have long argued the case for reading the book of Nahum as resistance literature and attributed particular importance to the poetic nature of the Nahum text. The author argued that the prophet or poet appealed to the imagination of his audience to perceive an alternative reality to the one they currently experience. While they were currently experiencing oppression, the call was to imagine the situation where the enemy is destroyed by the hand of Yahweh. By imagining the destruction of the enemy, hope was created for the people of Judah of a future of freedom which Yahweh will bring about (Wessels 1998:615-628). This brings up the idea of Jindo, as mentioned, that metaphors serve the purpose to 'reframe or restructure the conceptual knowledge' of the audience.

The prophet or poet Nahum, as a child of his time, used metaphors people could relate to at the time of the delivery of

4.The two verbs "to mourn" (נוד) and 'to comfort' (ניד Piel) are also used together in Psalms 69:21; Job 2:11, 42:11. Spronk (1997:125) is of opinion that Nahum 3:7 had an influence on Isaiah 51:19 where similar questions are applied to Jerusalem.

5.Besides van Hecke's reference to the great variety of views and approaches to metaphor studies in the Hebrew Bible, the collection of articles included in the book of which he is the editor, will clearly illustrate the complexity of metaphor studies (cf. van Hecke 2005:1-283). 
his prophetic proclamation or the time of its literary fixation. It is understandable in a context of war and domination that the prophet would use metaphors from this context to counter the enemy's acts of war and oppression. Yahweh as the supreme power would trump the power of the Assyrian enemy or any such enemy who will rise in future. This would explain the imagery and metaphorical references to war and destruction (Divine Warrior). Furthermore, within the context of a patriarchal society, it was common practice to depict women in less favourable ways. There are numerous examples in the Hebrew Bible of women being depicted as the weaker sex, as tricksters (Rebecca, Samson), as harlots (Proverbs) to mention a few. We often find the use of the marriage metaphor to depict the unfaithfulness of the people of Judah and Israel (as wife) in their relationship with Yahweh (Jr 2 and Ho 3).

A cultural sensitive reading of the text of Nahum should acknowledge the cultural conventions of the time which gave rise to the text under discussion. The metaphors and imagery of atrocious battle scenes and derogatory references to Nineveh as a harlot in Nahum 3 reflect the cultural conventions of ancient times. It is clear from the Wirkungsgeschichte of the Nahum text that many people in oppressive contexts could relate to the metaphors and imagery of the Nahum text (cf. Coggins \& Han 2011:9-11, 14-15; Wessels 2014:889-890). It provided hope and comfort to many to recognise that empires come and go and that ultimately Yahweh will destroy the enemies of his people. This, however, does not deny the fact that these metaphors and imagery cause uneasiness to modern readers of the text. I have previously expressed the view that Nahum's language and metaphors are purposefully extreme expressions of anger and frustration by oppressed people; however, it should not be taken literally as a summons to violence (Wessels 1998:615-628). By saying that I understand the anger and frustration of the oppressed people still does not justify the use of such language and imagery. I fully concur with the views of both Tuell (2016:45) and O'Brien (2009:115) that words have power and therefore have the potential of inciting and justifying violence, derogative language and name-calling. What follows now is an example of cultural readings of the Nahum text by some contemporary interpreters.

\section{A reading of Nahum sensitive towards the modern culture}

For the purpose of this article, a reading is presented from a modern approach to the text of Nahum. The so-called 'modern culture' of focus is a feminist critical reading of Nahum 3. This approach in biblical criticism is more interested in the ethical and ideological concerns as a result of engagement with the biblical text, than with historical matters regarding the text. The preferences and presuppositions of the modern biblical critic are therefore more in focus in this reading process.

\section{Feminist criticism on the use of Biblical metaphors}

Under the description of 'Feminist biblical criticism', many different approaches and methodologies are housed. The discussion offered by Maier and Sharp (2013:3-10) testifies to the variety of methodological approaches and wide-ranging issues of concern for feminist biblical interpreters. The central issue of concern amongst these approaches is the patriachal nature of the Bible. ${ }^{6}$ Maier and Sharp (2013) says in this regard:

Feminist interpreters laid bare the androcentric bias of biblical texts for readers who may have never before questioned the ways in which authority and truth had been shaped in ancient patriarchal contexts. (p. 3)

The concern is therefore not only the patriarchal nature of the Bible but also the predominant male interpretation of texts which is a perpetuation of patriarchy. In a chapter dedicated to feminist biblical criticism, Davies (2013:36-60) not only offers an overview of feminist biblical scholarship but also structures the chapter according to three different approaches promoted by contemporary feminist scholars. This is a helpful endeavour because it is impossible to discuss the wide-ranging feminist viewpoints in the space of this article. These approaches entail The rejectionist-, The revisionist- and The readerresponse approaches.

The strongest proponent of the rejectionist approach is Mary Daly, who encourages feminists to abandon everything that has to do with Judeo-Christian religion and opt for a postChristian faith. She rejects everything that is associated with patriarchy and its negative power and influence. She argues, according to Davies (2013) that:

patriarchy was not some separate attribute of Judaism that could be purged from the Bible; rather, it was an intrinsic characteristic of biblical faith and was something that was woven into the very fabric of ancient Israelite society. (pp. 41-42)

Needless to say, not all feminists are in favour of this radical approach, because they argue that much of their identity has been formed by the Judean-Christian religion.

Another group of feminists who are categorised under the revisionist approach still believe that the Bible should be taken seriously. They argue that the Bible should not be taken at face value because women played a much more significant role in their society than the biblical authors and later redactors allow us to see. These scholars see the task of feminine biblical scholarship as:

to embark on a systematic study of the neglected duties and functions of women in both ancient Israelite society and in the life of the early church, thus ensuring that their contribution was not completely obliterated from the biblical record. In order to achieve this aim, they tended to highlight the forgotten traditions

6.The article of Kalmanofsky (2011:190-208) entitled The Monstrous-Feminine in the Book of Jeremiah is an excellent example of how the issue of the patriarchal bias of a prophetic text is grappled with from a feminist perspective. 
of the Bible and to reinterpret texts that had been skewed or misunderstood by subsequent commentators down the centuries. (Davies 2013:44)

Amongst this group of feminist scholars is Carol Meyers, who follows a historical approach to the Old Testament, arguing that the social reality of ancient Israelite society was far more complex than the written records suggest. Another prominent scholar in this category is Phyllis Trible, who favours a literary approach. The biggest concern with this approach is that we have limited access and therefore knowledge of the various societies from which the various biblical texts emerged. These scholars are justified in searching for clues that could counterbalance the overarching patriarchal dominance obvious in the biblical texts.

The reader-response approach followed by feminist biblical scholars encompasses a diverse variety of methodologies, but what the proponents of these various methodologies have in common are that they are known as 'resisting' or 'dissenting' readers (Davies 2013:49). This approach was advanced by a literary critic Judith Fetterley who studied American literature. She concluded that American literature was written from a male perspective, displayed male presuppositions and was aimed at predominantly male audiences. This approach resonated with feminist biblical scholars who as a result adopted adversarial attitudes towards the biblical text (Maier \& Sharp 2013:7). As Davies (2013:50) states, what is mutual is the underlying supposition 'that the act of reading should involve resistance to the dominant structures of power inscribed in the biblical text'.

What became clear from the above discussion is that patriarchy is the key issue in feminist biblical criticism. It is, however, not only the patriarchal language of the text that is of concern but also that the various texts stem from a patriarchal society. But even more than that is the perpetuation of the patriarchal perspective offered by the text reflected in the interpretation process and the neglect of critically engaging the patriarchal entitlement. Feminist biblical critics, therefore, have a legitimate cause they pursue. It is interesting to note that from a Womanist critical approach to the Bible mainly by African-American scholars, not only the patriarchal biblical text is taken to task but also the Eurocentrism of feminist biblical interpretation. The argument is that aspects, such as race, religion, nationality, sexual orientation and socio-economic circumstances, should form part of the equation when biblical texts are critically interpreted (cf. Davies 2013:57-58). This in view of the Womanist approach is not done by Eurocentric feminists.

There are currently many scholars who offer feminist interpretations of the prophets. They have serious concerns with the way some prophetic texts portray women in metaphors to depict the Israelite people as adulterous and promiscuous. Some of the passages of concern are Hosea 2, Jeremiah 2-3 and Ezekiel 16 and 23. Maier (2016:467-482) in this regard offers an insightful presentation of feminist interpretation of the prophets as mentioned. The Nahum 3 text, in particular, is of concern because of the metaphor of a harlot (3:4) to refer to Nineveh and also the depiction of weakness and humiliation in Nahum 3:5-7. Scholars such as O'Brien (2009:61), Coggins and Han (2011:31-32) and Tuell (2016:41-42) have discussed the serious problems feminist readers have with passages such as Nahum 3:4-7 and as a consequence even regard them as pornography. Exum (2015) states in this regard that:

texts are pornographic because they involve objectification, domination, vindictiveness, pain and degradation. They raise serious ethical questions not only because they are offensive and demeaning, but also because they could be seen to give biblical sanction to the sexual abuse of women. (p. 121)

For feminist interpreters, this is also true of Nahum 3:4-7 where the city is depicted as a woman and the conquest regarded as rape. On the one hand, Nineveh is depicted as 'the prostitute, gracefully alluring' (3:4), but on the other hand, the city is depicted as the victim of rape - to which Tuell (2016:41) remarks ' $[i t]$ sounds unnervingly like a rapist's claim that this victim was "asking for it"'. Feminist biblical interpreters have serious concerns about the objectification of women and the stereotyping of women as adulterers and weak (e.g. O'Brien 2010:115-122, 128-130). I will, however, not focus on feminist interpretations as such in this article, but mainly focus on one modern view that is sensitive towards feminist critique, yet offers a broader discussion of Nahum 3.

One of the most vocal voices on the Nahum text is Julia O'Brien, who wrote a commentary on the book of Nahum in 2002, of which a second edition appeared in 2009. She also wrote a book in 2008 entitled Challenging Prophetic Metaphor. Theology and Ideology in the Prophets, in which she dedicates one of the chapters to the book of Nahum. In this chapter, she discusses God as (Angry) Warrior (O'Brien 2008:101-124).

Julia O'Brien could be associated with feminists who approach biblical texts from a reader-response perspective. She follows a literary approach to Nahum, which allows her to focus on the great variety of literary features this piece of literature has to offer. She has a keen interest in the ethical issues the Nahum text raises and therefore the historical placing and dating of the text is not of interest to her $\left(\mathrm{O}^{\prime}\right.$ Brien 2009:1-11; cf. also Maier \& Sharp 2013:8). Besides the focus of her approach on the rhetorical dimensions of Nahum, $\mathrm{O}^{\prime}$ Brien has a keen interest in the ideological dimensions of the Nahum text, which concern how power is manifested in terms of race, class and gender. O'Brien (2009:13) emphasises the fact that she regards herself as 'the reader' of Nahum, but states that her approach is to also dialogue with the readings others have done. She unreservedly declares her feminist interests and for that reason, Nahum 3 receives particular focus with its personification of Nineveh as a woman. In her discussion of the personification of Nineveh as a woman, patriarchy and its display of power dominance as revealed in 
the use of denigrating imagery ${ }^{7}$ is significantly in focus. In this regard, the issue of patriarchy, which is key in all feminist approaches, is taken to task by O'Brien. She also raises the issues of race and class, so important to Womanist approaches, by discussing how the Other is portrayed in the book of Nahum (O’Brien 2009:13).

Two aspects of the Nahum text, in particular, are cumbersome to O'Brien. One is the atrocious description of violence and what she calls the 'demonization of the Other' (O'Brien 2009:122). She says about the oppressor as the 'Other': 'The more unsympathetic, faceless and totally "Other" the oppressor can be seen to be, the more easily its obliteration can be cheered' (O'Brien 2009:122).

The concept 'Othering' forms part of psychoanalytic theory. The following quotations will shed light on the idea of the Other: 'the problem of the Other is always a problem of the Self. The construal of the Other is an attempt to shape one's own identity'; With regard to the Other and the Self the following: 'the apparent opposites are inseparably bound together, depending upon each other for the meaning'; and 'without the Other, the Self loses all points of reference' ( $\mathrm{O}^{\prime}$ Brien 2009:123). One has to agree with $\mathrm{O}^{\prime} B$ Brien that this is indeed a worrying matter for which awareness should be raised.

The second aspect she finds most disturbing is the use of female metaphors in Nahum 3 to depict the city of Nineveh as a prostitute and a harlot (promiscuous woman), the humiliation of the woman (Nineveh) by exposing her nakedness to the world and the fact that this will be done by Yahweh self (O'Brien 2009:62). In this whole depiction, she indicates that patriarchy is the underlying ideological structure. Therefore, in O'Brien's view, two basic ideologies form the framework within which the text of Nahum operates, namely that of 'Patriarchy' and 'Othering' (O'Brien 2009:128, cf. also O'Brien 2008:67-75 on feminist critique of the book Hosea with regards to patriarchy). O'Brien is sympathetic to a reading that emphasises the voice of resistance to oppression, a reading I endorse, but she cannot see a way in any sense of condoning violence ascribed to Yahweh, the Othering of the enemy and the derogatory language and rhetoric to do so. It is perhaps suitable to end this section with a quote from $\mathrm{O}^{\prime}$ Brien (2009:128): 'I and the culture in which I live are implicated in and complicated by the Othering function of language and society that runs through the book of Nahum.'

The issues $\mathrm{O}^{\prime}$ Brien raises are real issues and cannot simply be dismissed. I have an appreciation for the fact that she does not dismiss the Nahum text outright because of her views on patriarchy and concern for the faceless enemy (the people that are part of the collateral damage of war and violence). Whether we agree or disagree with her, her reading of the

7.In her article 'Prophetic Pornography Revisited', Cheryl Exum (2015:121-139) examines texts from the books of Hosea, Isaiah, Jeremiah and Ezekiel where denigrating imagery of women is used. Under a heading (Metaphorical) Violence against Women-Does it 'Atter?, she summarises various attempts to deal with this concern and concludes, 'A fundamental point of the feminist critique is that the us of imagery of female sexual sin and female sexual abuse as a means of representing male social and political sins and their consequences reflects what amounts to devaluation and denigration of women' (Exum 2015:136).
Nahum text is clearly a culturally informed reading based on a more current worldview and ideological preferences.

\section{Concluding remarks}

Most serious exegetes would agree that the reading of texts, in this case, a prophetic text, should first and foremost be interpreted in its historical and social context. This is also true for many, not all, feminist critics who are offended by the content of a prophetic text such as Nahum 3. Maier (2016) regards the above-mentioned point as the first step, but then continues saying:

In the second step, the existence of kyriarchal norms and gender-hierarchical relationships in the texts should be disclosed in order to disrupt any potential harmful effect on modern readers. Therefore, many feminist readings deconstruct implicit androcentric assumptions or values. (p. 479)

What I have realised is that as readers or hearers of the text, we react to and give meaning to the text. Our cultural embeddedness plays a major role in the process of 'meaninggiving' to the texts we interpret. However, there should be accountability for the meaning we give and promote. Scholars have different suggestions on how to deal with this matter. Tuell for one, suggests a canonical approach to the interpretation of Nahum because it will prevent 'an uncritical embrace of Nahum's simplistic, black and white ideology' (Tuell 2016:12). He argues that the incorporation of Nahum in the Book of the Twelve provides a theological context that tempers the one-sidedness of his view on Yahweh's justice and vengeance. Both Habakkuk and Jonah provide broader perspectives on Judah's imperfections and saving grace for Nineveh that should be considered when Nahum is interpreted. However, a canonical approach would imply that a New Testament perspective should also come into play.

A theological reading of this particular text in Nahum 3 would emphasise the justice of Yahweh, the loyalty of Yahweh to those who belong to him and the hope there is for God's people. However, we should be critical of patriarchy and the perpetuation of the negative implications patriarchy has for people who are created equal in the image of God. Tuell challenges readers of the vengeful text of Nahum and the delight this text portrays in the downfall of 'the Other', to do some introspection. He says the following about the effect of negative emotions reflected in Nahum 3 on people who take the biblical text seriously:

Indeed, Scripture often confronts these emotions directly and honestly. Recognizing the presence and power of these emotions before God in prayer provides catharsis: the spleen vented, the poison drawn, we are freed to live our lives in joy, not anger; in love, not hatred. Reading Nahum, then, provides the opportunity for the recognition of these dark emotions in ourselves and in our world -a recognition that ought to lead us not to jingoism and the pursuit of vengeance but to earnest repentance and the pursuit of peace. It also calls us to confess these sins and pray for the redemption of a world still in thrall to violence and retribution. (Tuell 2016:13)

It should be said loud and clear that we first and foremost have to take the text we analyse seriously as a text in its own right. The social and historical context of a text should be 
acknowledged as a point of departure. It is, however, also true that we as readers and interpreters of biblical texts are also socio-historically situated which plays a part in our understanding and how we create meaning. Besides these facts, we also belong to or associate with certain 'cultural' groupings in society that influence our way of thinking and preferences. As interpreters, we have methodological preferences that will affect our understanding and meaningmaking. We will also never escape our ideological biases, which are informed by the 'cultures' we choose to associate with. For any constructive dialogue, we need to acknowledge our ideological biases, reflect on them critically and realise that no one of us has the exclusive right to claim to have the truth. When we arrive at ideas and promote the meaning we have arrived at, we should take responsibility for them and be willing to defend them in the public space.

Cultural sensitive readings of Nahum 3 should alert us to the negative consequences not only of patriarchy, but also of 'Othering' people. God so loved the world, that the 'Others' are also important to him, and therefore to us. Imagery and metaphors are not cast in stone, but are cultural specific phenomena. Maier (2016:479) remarks that as 'metaphors are time and culture-specific, the task at hand is first to explain the metaphors with regard to their original social-historical context and then to interpret them with regard to modern readers'. We should find ways and means to be culturally relevant to people in a modern context and to be bold enough to criticise and reject derogatory and abusive imagery and metaphors.

\section{Acknowledgements Competing interests}

The author declares that he has no financial or personal relationships which may have inappropriately influenced him in writing this article.

\section{References}

Coggins, R.J., 1985, Nahum, Obadiah, Esther. Israel among the Nations, Eerdmans, Grand Rapids, MI.

Coggins, R. \& Han, J.H., 2011, Six minor prophets through the centuries, WileyBlackwell, West Sussex.

Davies, E.W., 2013, Biblical criticism. A guide for the perplexed, Bloomsbury, London.

Dietrich, W., 2014, Nahum, Habakuk, Zefanja, Kohlhammer, Stuttgart.

Exum, J.C., 2015, 'Prophetic pornography revisited' in R.I. Thelle, T. Stordalen \& M.E.J.' Richardson (eds.), New perspectives on Old Testament prophecy and history. Essays in honour of Hans M. Barstad, pp. 121-139, Brill, Leiden.

Floyd, M.H., 2000, Minor Prophets Part 2, Eerdmans, Grand Rapids, MI.

Jindo, J.Y., 2010, Biblical metaphor reconsidered: A cognitive approach to poetic prophecy in Jeremiah 1-24, Eisenbrauns, Winona Lake, IN.

Kalmanofsky, A., 2011, 'The monstrous-feminine in the Book of Jeremiah', in A.R.P Diamond \& L. Stulman (eds.), Jeremiah (dis)placed. New directions in writing/reading Jeremiah, pp. 190-208, T\&T Clark, New York.

Maier, C.M., 2016, 'Feminist Interpretation of the Prophets', in C.J. Sharp (ed.), The Oxford handbook of the prophets, pp. 467-482, Oxford University Press, New York.

Maier, C.M. \& Sharp, C.J., 2013, 'Introduction: Feminist and postcolonial interventions in and with the book of Jeremiah', in C.M. Maier \& C.J. Sharp (eds.), Prophecy and power. Jeremiah in feminist and postcolonial perspective, pp. 1-18, Bloomsbury, London.

Merriam-Webster's Dictionary, viewed 02 Mar. 2018, from https://www.merriamwebster.com/dictionary/culture

Nelson, R.D., 2014, Historical roots of the Old Testament (1200-63BCE), SBL, Atlanta, GA.

O'Brien, J.M., 2008, Challenging Prophetic Metaphor: Theology and ideology in the Prophets, Westminster John Knox, Louisville, KY.

O'Brien, J.M., 2009, Nahum, 2nd edn., Sheffield Phoenix Press, Sheffield.

O'Brien, J.M., 2010, 'Violent pictures, violent cultures? The "aesthetics of violence" in contemporary film and in ancient prophetic texts', in C. Franke \& J.M. O'Brien (eds.), Aesthetics of violence in the Prophets, pp. 112-130, T\&T Clark, New York.

Robertson, O.P., 1990, The books of Nahum, Habakkuk and Zephaniah, Eerdmans, Grand Rapids, MI.

Spronk, K., 1997, Nahum, Kok Pharos, Kampen.

Tuell, S., 2016, Reading Nahum-Malachi: A literary and theological commentary, Smyth \& Helwys, Macon, GA.

Van Hecke, P., 2005, 'Metaphor in the Hebrew Bible. An introduction', in P. van Hecke (ed.), Metaphor in the Hebrew Bible, pp. 1-17, Peeters, Leuven.

Wessels, W., 1998, 'Nahum: An uneasy expression of Yahweh's power', OTE 11, 3, 615-628.

Wessels, W.J., 2014, 'Nahum', in G.A. Yee, H.R. Page Jr. \& J.M.M. Coomber (eds.), Fortress commentary on the Bible. The Old Testament and Apocrypha, pp. 889-890, Fortress, Minneapolis, MN. 